\title{
Látogatómenedzsment a hazai védett természeti területeken
}

\author{
Szerzők: Benkhard Borbála ${ }^{1}$ - Martonné Erdős Katalin²
}

A védett természeti területeken folyó turizmus tervezésekor, szervezésekor az értékek védelme érdekében kiemelt figyelmet kell fordítani a látogatómenedzsment-technikák tudatos és széles körú alkalmazására. Míg külföldön ennek a kérdéskörnek a kutatottsága, szakirodalma és gyakorlati alkalmazása egyaránt jelentôs, addig hazánkban az egyes eszközök elönyei kevésbé ismertek, illetve korántsem aknázzuk ki a bennük rejlő lehetôségeket. Az egyes védett területeken bevezetett intézkedések, technikák között tapasztalható különbségek többnyire az eltérô területi adottságokra vezethetôek vissza. Ugyanakkor megfigyelhetö, hogy a nemzetipark-igazgatóságok ökoturisztikai szakemberei eltérôen vélekednek azok hatékonyságáról és elfogadottságáról, aminek oka a látogatók körének különbözósége mellett az alkalmazható, illetve alkalmazott módszerek előnyeinek alacsony kihasználtsága.

Kulcsszavak: látogatómenedzsment, ökoturizmus, védett természeti terület.

\section{Bevezetés}

A hagyományos látogatómenedzsment-technikák középpontjában a látogató és a szolgáltató áll. Céljuk a látogatói élmény fokozása, a keresletnek megfelelő termék, differenciált szolgáltatáscsomag kialakítása, az attrakció ismertségének, elismertségének erôsödésén keresztül a bevételek növelése és a szezonalitás csökkentése (RÁTZ 2011). Ezekkel szemben a védett területek esetében - mint ahogyan azt EAGLES és munkatársai (2002) kihangsúlyozzák - a látogatómenedzsment elsődleges célja a látogatók nagy számából, tevékenységéből fakadó problémák kezelése. Az ilyen hozzáállással kidolgozott látogatómenedzsment-stratégia fő jellemzői, célkitúzései az alábbiak:

- ellenórizni (a területre érkezők viselkedését),

- befolyásolni (a látogatói döntéseket),

- csökkenteni (a turisták környezetre gyakorolt hatását).

Magyarország védett természeti területei eltérő mértékben látogatottak, azonban a turisták

\footnotetext{
'egyetemi tanársegéd, Debreceni Egyetem; ügyvezetö, SCIAP Kft., benkhard.borbala@science.unideb.hu

${ }^{2}$ nyugalmazott egyetemi docens, Debreceni Egyetem,

martonnekati@gmail.com
}

igényeit is figyelembe vevő tudatos látogatómenedzsment-intézkedések alkalmazására a természeti értékek megőrzése érdekében mindenütt szükség van. Hazánkban a védett területek látogatómenedzsmentjének helyzete bizonyos sajátosságokat mutat. Ezek az alábbiakban foglalhatóak össze:

A hatékony menedzsmentterv kialakításához, illetve a megfelelő eszköz kiválasztásához alapvető fontosságú az adott terület látogatóforgalmának ismerete. A hazai természeti területek adottságai miatt azonban ezekről a területekről szinte semmilyen látogatóstatisztikai adattal nem rendelkezünk, nem vagyunk tisztában az oda érkező turisták jellemzóivel.

A hazai turisztikai szakirodalom látogatómenedzsment-tevékenység alatt többnyire csak az adott terület ismertségének növelését, a látogatói elégedettség erősödését és a bevételek fokozását érti. Az épített környezethez képest jóval kevesebb (vagy szinte semmilyen) szolgáltatást nyújtó természeti környezetben a "hagyományos" célok mellett a látogatómenedzsment elsődleges feladata a terhelés csökkentése.

A téma fontossága (növekvő érdeklődés és látogatottság) valamint aktualitása (például a Bejárható Magyarország Program, Nemzeti Tájstratégia megszületése) miatt szükségesnek látjuk áttekinteni a hazai védett természeti területeken (1. ábra) bevezetett látogatómenedzsment-intézkedéseket. 
Nemzetipark-igazgatóságok (NPI) múködési területei és a védett területek elhelyezkedése

1. ábra

\section{Jelmagyarázat}

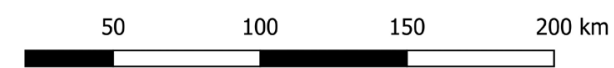

Nemzeti park

Tájvédelmi körzet

- Természetvédelmi terület

$\square$ Nemzetipark-igazgatóságok müködési területének határa

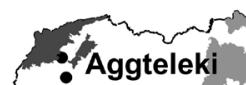

Aggteleki
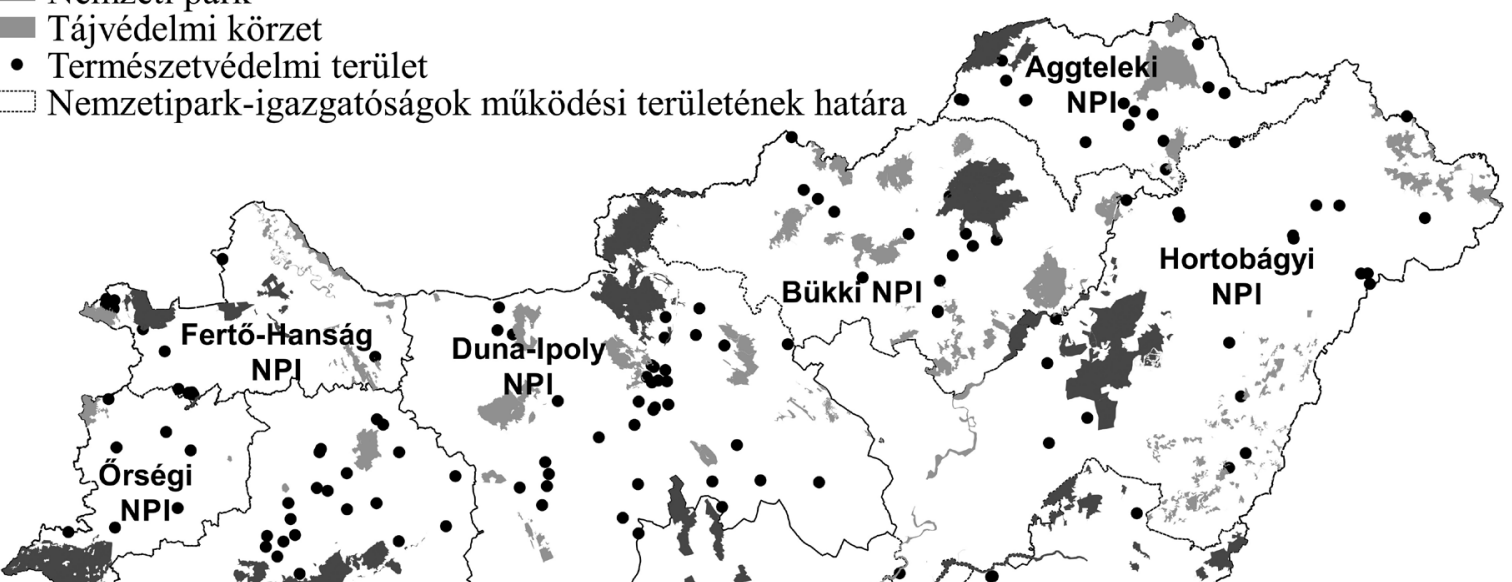

a.

Balaton

Balaton-felvidéki

NPI
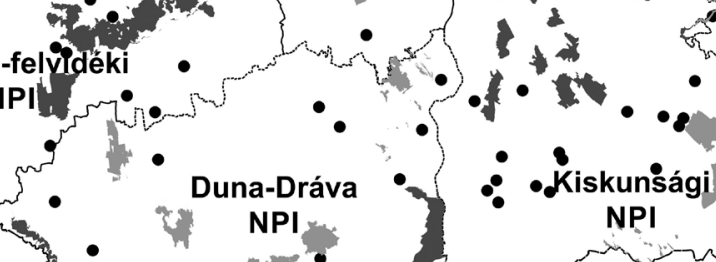

Dus
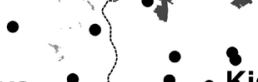
$\therefore$ - KKiskunšági
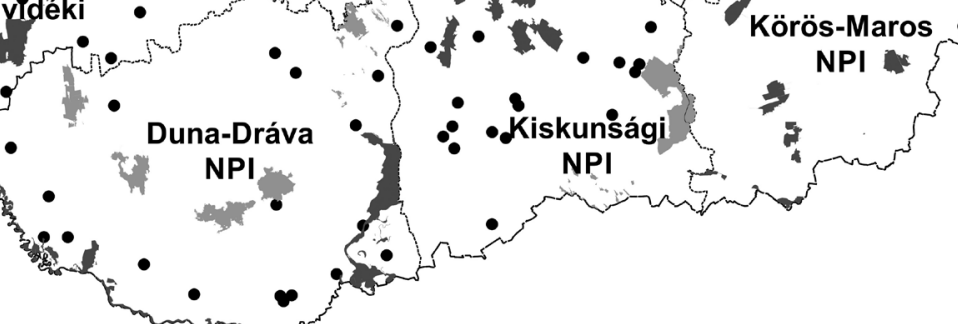


\section{Elméleti háttér}

A gyakorlatban is használatos stratégiákat a szakirodalomban eltérő szempontok szerint csoportosítják (EAGLES et al. 2002, NEWSOME et al. 2001, PÉNZES et al. 2008). Megkülönböztethetóek közvetett és közvetlen módszerek, elkülönítendőek a látogatómenedzsment-eszközök és az úgynevezett területi menedzsment (site management). Csoportosítási szempont lehet az is, hogy a használatot egy-egy területre korlátozzák, vagy éppenséggel direkt szétszórják, eloszlatják. Egyes stratégiák a látogatók által gyakorolt hatások forrása, illetve a terhelés helyszíne alapján különítik el az intézkedéseket, mások a látogatók által használt erőforrások kínálata, illetve tartóssága szerint határozzák meg azokat. A legáltalánosabb csoportosításról a 2. ábra ad áttekintést.

A külföldi és hazai szakirodalom (EAGLES et al. 2002, EAGLES - McCOOL 2004, KVVM 2005, NEWSOME et al. 2001, PÉNZES et al. 2008, PUCZKÓ - RÁTZ 2000), saját tapasztalatok és hazai ökoturisztikai szakemberek, természetvédelmi őrök véleménye (szóbeli közlése) alapján az egyes látogatómenedzsment-eszközöket és azok lehetséges előnyeit foglaltuk össze a 3. ábrán.

\section{Látogatómenedzsment-eszközök lehetséges elônyei}
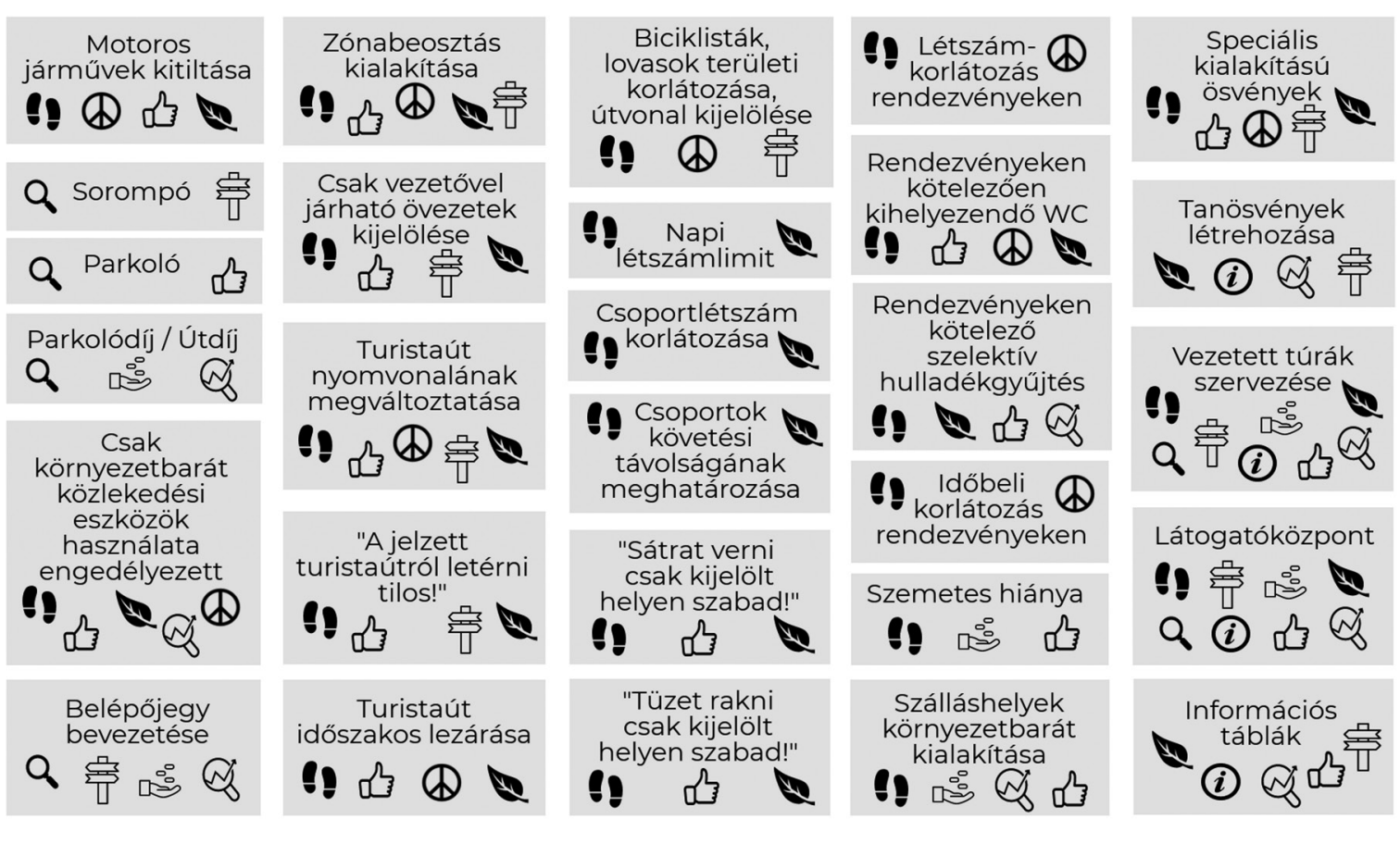

Q8 terhelés csökkentése

Q értékek védelme

D közös használatból eredő konfliktus elkerülése
Q látogatómonitoring

员 látogatóáramlás irányítása

$\Omega$ látogatók viselkedésének befolyásolása
प气े gazdasági szempontok

W marketingeszköz

(i) tájékoztatás

Forrás: saját szerkesztés a szakirodalom és saját adatgyüjtés alapján

\section{Módszer}

A 3. ábra alapján látható, hogy egy-egy eszköz, intézkedés nem feltétlenül sorolható be kizárólagosan csak a látogatóirányítási módszerek vagy a területi módszerek közé. Jelenlétük, megítélésük, lehetséges előnyeik kihasználtsága külföldön és hazánkban is változó. A tudatos menedzsment-tevékenységek megjelenésének ideális sorrendje eltér a hazánkban tapasztalhatóaktól, mivel az in- 
Lektorált tanulmányok

formálás, tájékoztatás kellene, hogy legyen az elsô lépés, a terület kezelójének megjelenése a második, és csak ezt követik - szükség esetén - a szabályozások, korlátozások (EAGLES - McCOOL 2004). Magyarországon ez azonban más sorrendben jött létre. Nemzeti parkjaink egymástól eltérő mértékben, fokozatosan váltak a turizmus célterületeivé (MICHALKÓ 2003). A hegyvidéki területeken már a védetté nyilvánítás előtt (a XX. század elejétôl) is jelentôs volt a látogatóforgalom, elsősorban a túrázóknak köszönhetóen.

A menedzsment-eszközök alkalmazása (elfogadottsága), illetve lehetséges előnyeik kihasználása függ az adott terület kultúrájától, a látogatók ismereteitől, valamint a rendelkezésre álló erőforrásoktól (BELL et al. 2007, EAGLES - McCOOL 2004, NEWSOME et al. 2001).

A természeti értékek védelmének és a látogatói élmény fokozásának összehangolása érdekében fontos a menedzsment-eszközök minél szélesebb körú és tudatos alkalmazása. Ennek eléréséhez elsô lépés a helyzetelemzés. A hazai látogatómenedzsment-intézkedések helyzetét (előfordulását), megítélését a magyarországi nemzetipark-igazgatóságok (továbbiakban: NPI) ökoturisztikai szakembereinek elküldött egységes kérdéssor alapján tártuk fel 2016 folyamán. A kérdéssor az alábbi eszköz- és intézkedéstípusokra terjedt ki:

- jogszabály írja eló,

- valamelyik védett területünkön (nemzeti park, tájvédelmi körzet, természetvédelmi terület; továbbiakban: NP, TK, TT) már bevezették,

- hazánkban nem alkalmazott, de külföldön tapasztalt vagy szakirodalomban hivatkozott (EAGLES et al. 2002, LEUNG et al. 2014, NEWSOME et al. 2001) eszköz.

A megkérdezett szakembereknek az előzô témakörökben a következő kérdésekre kellett válaszolniuk:

- Melyik eszközt, intézkedést alkalmazzák bármely - saját hatáskörükbe tartozó - védett természeti területükön (NP, TK, TT)?

- A korlátozások betartását milyen eszközökkel segítik?

- Melyik intézkedést mennyire tartják hatékonynak (1-tól 5-ig terjedő skálán) a desztináció védelme szempontjából?

- Mennyire bizonyultak a bevezetett intézkedések elfogadhatónak (1-tól 5-ig terjedő skálán) a látogatók számára?

A hatékonyság és elfogadottság értékelésekor a válaszadóknak lehetôségük nyílt a „nem alkalmazott" válasz bejelölésére is, ha a saját múködési te- rületükön a szóban forgó intézkedést nem foganatosították.

\section{Eredmények}

\subsection{LÁTOGATÓMENEDZSMENT-ESZKÖZÖK ALKALMAZÁSA}

A védett területek esetében fontos menedzsment-eszköznek tekinthetô a zónák kialakitása. Az 1996. évi LIII. törvény a természet védelméről (továbbiakban: Tvt.) kimondja, hogy - a nemzetközi előírásokkal összhangban - a nemzeti parkokat övezeti kategóriákba ${ }^{3}$ kell besorolni [28.§ (7) bekezdés]. Az erről szóló szakmai döntés nemzetipark-igazgatóságonként eltérő szinten áll. Ahol megszületett a döntés, ott sem minden esetben rögzítették jogszabályban az övezeteket (például a Duna-Ipoly Nemzeti Park Igazgatóság - továbbiakban: DINPI - esetében). A turisztikai fejlesztések és a turisták tájékoztatása ugyanakkor már a zónák (övezetek) figyelembevételével történik. A nemzeti parkok adottságai, például azok mérete, mozaikossága, valamint a turizmushoz való viszony a látogatók számára szabadon látogatható úgynevezett $C$ zóna méretét, arányát és alakját alapvetóen befolyásolják (BENKHARD 2004).

Jogszabálynak (Tvt., illetve az Erdőről, az erdő védelméről és az erdőgazdálkodásról szóló 2009. évi XXXVII. törvény, továbbiakban: Etv.) való megfelelés következménye, hogy a motoros jármúveket bizonyos védett természeti területekról kitiltják. Ezt a korlátozást sorompók kihelyezésével igyekeznek betartatni (BNPI, DINPI, HNPI), valamint a konfliktus elkerülését több helyen parkolók kialakításával segítik (ANPI, BNPI, HNPI). A korlátozás okáról azonban csak kevés helyen (BNPI, DINPI, HNPI) tájékoztat tábla. A múutakra való behajtást ugyanakkor az eltérő területhasználati érdek (erdôgazdálkodás, magántulajdon) gyakrabban gátolja, mint a természetvédelmi elóírások. Ennek betartását esetenként szintén sorompókkal, parkolókkal, tájékoztató táblákkal segítik (az erdôgazdaság, honvédség, vízügyi igazgatóság, önkormányzat, magán gazdálkodó, turisztikai vállalkozó).

A nemzeti parkok területén kialakított parkolóhelyeknél csak néhány esetben kell parkolási díjat fizetni (BNP, DINP, HNP) a parkolót létrehozó, illetve múködtető (nemzetipark-igazgatóságtól eltérő) szervezet részére.

${ }^{3}$ A zóna: természeti övezet, B zóna: természetkímélő hasznosítás övezete vagy kezelt természeti övezet, $\mathrm{C}$ zóna: bemutató vagy szolgáltató övezet (134/2013. (XII. 29.) VM rendelet a nemzeti parkok területének övezetekbe való besorolásáról és az egyes övezetekre vonatkozó általános természetvédelmi előírásokról). 
A külön engedély nélkül látogatható védett természeti területeken belépődijat szinte minden esetben csak bemutatóhely (például látogatóközpont, tanösvény) megtekintésével egybekötve kell fizetni, amelyre minden nemzeti parkunk területén találunk példát. Az egyes nemzetipark-igazgatóságok által meghatározott, szabadon (engedély, illetve vezetón nélkül) látogatható területekre történó belépés hazánkban ingyenes.

A vezetett túrák kialakításánál az egyes nemzetipark-igazgatóságok eltérő szempontokat vettek figyelembe (4. ábra), bár elsődleges célként mindenki a hatékony bemutatást és a környezeti nevelést jelölte meg. Ellenőrzött áramlási útvonalként a B zónában jutnak legtöbbször szerephez. A legkevésbé fontos szempont a zsúfoltabb területek, útvonalak terhelésének csökkentését szolgáló, vezetett túrák látogatóit megcélzó, alternatív célpontok és útvonalak bemutatása, ismertté tétele.

\section{Nemzetipark-igazgatóságok (10 db) által vezetett túrák kialakításának célja}

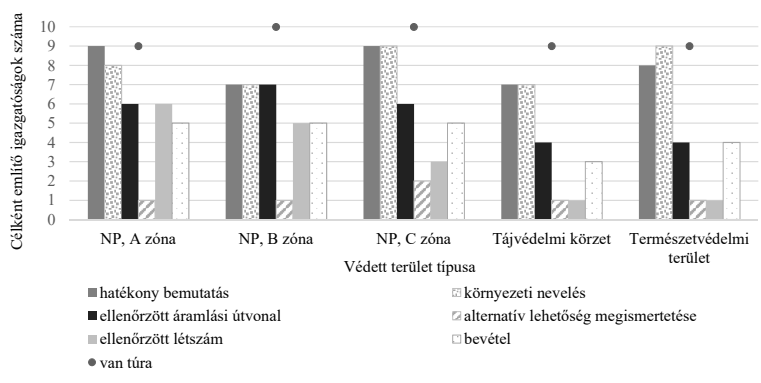

Forrás: saját szerkesztés saját adatgyüjtés alapján

Minden nemzeti parkot érintő törvényi szintú általános szabály, hogy a fokozottan védett területeken a jelzett turistaútról letérni tilos (Tvt.). A területi korlátozások okáról - különös tekintettel az A zónára, ami sok esetben egybeesik a fokozottan védett területekkel - táblán tájékoztatják a turistákat. Egyes esetekben a nemzeti parkok A és B zónájában, illetve a fokozottan védett területeken csak vezetốvel járható övezeteket jelöltek ki (BNP, DINP, FHNP, HNP, KMNP, KNP).

Hazánkban is egyre gyakoribb (minden nemzetipark-igazgatóság múködési területe esetében találunk rá példát), hogy az „úton tartást” tájba illesztett múvi elemek, például pallóút, lépcsősor, vagy speciális burkolású ösvény, kialakításával érik el. Ezen megoldások a természeti értékek védelmével párhuzamosan a látogatók kényelmét, valamint több esetben az akadálymentességet is szolgálják.

A szabadon, belépójegy nélkül látogatható területeken egyes útszakaszok, területek átmeneti lezárása (például fészkelési időszakban), tehát az idôszakos korlátozás nem túl gyakori. Az időszakos korlátozások elfogadását, betartását alternatív útvonal kialakításával, felajánlásával igyekeznek segíteni (KMNP).

A csoportlétszám maximalizálásárólcsaka DDNPI, FHNPI és HNPI munkatársai tettek említést. Speciális korlátozás a DDNP területén a vízitúrák során betartandó 2 napos követési távolság, melyre Magyarországon máshol nincs példa. Ugyanakkor a vezetett túrák, például a barlanglátogatások során az előre meghirdetett idópontokban induló, maximalizált létszámú csoportok is az időbeli terhelés széthúzását eredményezik.

Védett területen megtartott rendezvényeknél az engedélyező hatóság indokolt esetben létszámbeli és idốbeli korlátozást alkalmaz.

A szemétgyứtoốk turistautak mentén történô kihelyezése egyre ritkább, a nemzeti parkok közül az ANP, HNP, KNP, ÓNP; tájvédelmi körzetek, természetvédelmi területek közül a DINPI, a KNPI és az ÔNPI múködési területén találunk rá példát a bemutatóhelyek közelében. Ennek az az oka, hogy inkább a látogatás során keletkezett hulladék hazavitelére ösztönöznék a kirándulókat, amire táblákon is felhívják a figyelmet (DDNPI, DINPI, FHNPI, HNPI).

A védett területen történő sátrazásról, valamint a túzrakásról is jogszabály (Etv., Tvt.) rendelkezik. Kevés kivételtól eltekintve az erre a célra kijelölt helyeken kívül tilos a sátrazás, ugyanakkor a kapott válaszok alapján nemzeti parki területen, de ott is csak a C zónában, találunk kijelölt sátorhelyet (DDNP, KMNP, ÖNP).

Minden nemzetipark-igazgatóság rendelkezik védett területen kialakított szálláshellyel, így annak környezetbarát múködtetése tőlük függ. Jóllehet majdnem minden szálláshely esetében megoldott a szelektív hulladékgyújjtés, a vízzel való takarékosság ösztönzésére sehol sem vezették még be (neveló célzattal sem) a vízfogyasztás korlátozását. A Kárpát-medence édesvízkincsének jó helyzete erre a magyarázat, ugyanakkor globális szinten ez az állapot, vízfelhasználási szint nem fenntartható.

\subsection{LÁTOGATÓMENEDZSMENT-ESZKÖZÖK MEGÍTÉLÉSE}

Ahogy az elózőekből is látható, a lehetséges eszközöket nem minden NPI alkalmazza. A gyakorlati szakemberek is eltérôen vélekednek ezek hatékonyságáról és arról, hogy mennyire elfogadhatóak a látogatók számára, jóllehet a felsorolt eszközök többségét összességében (az értékelések móduszát figyelembe véve) közepesen hatékonynak vagy jó hatékonyságúnak tartották (1. táblá- 
Lektorált tanulmányok

zat). E mutató alapján a leghatékonyabbnak és a leginkább elfogadottnak a vezetett túrák kialakitását ítélték, s ennek megfelelően minden igazgatóság él is ezzel az eszközzel. A legkevésbé hatékonynak és elfogadottnak az útvonalról való letérés büntetése bizonyult.

Az egyes intézkedések, eszközök hatékonyságára és elfogadottságára adott értékelések azonban több esetben is nagy szórást mutatnak. Legjellemzóbb ez a zónabeosztás hatékonyságának és elfogadottságának megítélésénél, illetve a belépójegyek segítségével korlátozott látogatóforgalom és az útvonalról való letérés büntetése hatékonyságának esetében, melyeknél a két szélsőséges érték egyaránt előfordul. A szemétgyüjtők kihelyezésének, valamint a szelektív hulladékgyüjtés lehetôségének értékelése szintén nagy változatosságot mutat mind a hatékonyság, mind az elfogadottság szempontjából, aminek az a magyarázata, hogy a védett természeti területek, illetve a kialakított bemutatóhelyek infrastruktúrája (például a megközelíthetőség jellege) és szuprastruktúrája (például a szálláshely jellege) nagyon eltérô. Összességében azonban a szemétgyújtők hiánya, illetve azoknak a kiépített bemutatóhelyekre történó visszaszorítása a jellemzó. Ennek az is az oka, hogy a desztináció, illetve a természeti értékek védelme szempontjából a szakemberek kevésbé tartják hatékonynak a szemétgyújtők kihelyezését (1. táblázat), mint amennyire ez szerintük a turisták számára elfogadható.

Az egyes menedzsment-eszközökre adott értékek változatossága mellett egyetlen esetben figyelhető meg összhang a válaszadók között: habár eltérô mértékben, de az elfogadottsághoz hasonlónak, vagy annál magasabb hatékonyságúnak ítélték meg a szabad sátorverés tilalmát.

Jóllehet, a nemzetipark-igazgatóságok szakembereinek értékelését csak a saját hatáskörükbe tartozó (múködési területükre eső) eszközökre, intézkedésekre vonatkozóan kértük, egyes esetekben - ahogy az 1. táblázatban látható - általuk nem alkalmazott eszközökről, intézkedésekrő is véleményt alkottak (lásd szürke csíkozással jelölt értékek). Ezt nem zavaró adatnak, hanem értékes információnak tekintjük, hiszen ezek az értékek magyarázhatják azt, hogy adott területen miért nem vezettek még be egy-egy intézkedést, vagy esetleg várható-e annak alkalmazása (a jelen jogi, természeti, társadalmi és gazdasági környezet változatlansága esetén). Így például az Őrségi Nemzeti Park Igazgatóság védett területein a turistautak nyomvonalának természetvédelmi okokból történó megváltoztatása egyelőre nem valószínúsíthetô, mert sem hatékonynak, sem - a látogatók által - elfogadottnak nem tart- ják a helyi adottságokat ismerő ökoturisztikai szakemberek.

A hatékonyság és az elfogadottság megítélése között eltérés figyelhető meg az egyes területek környezetbarát közlekedési eszközökkel való bejárása (eredeti megfogalmazásban „egyes területeken csak alternatív, környezetbarát közlekedési eszközök használatának engedélyezése", például kerékpárral történő közlekedés a Központi-Börzsönyben, vagy elektromos motorú csónakkal a Tisza-tó egyes részein) esetén is.

Az egyes eszközök hatékonyságának és elfogadottságának megítélése közötti eltérések különböző okokra vezethetőek vissza. A zónabeosztás kialakítása hiába jogszabályi előírás, egy-egy nemzeti park mozaikos szerkezete miatt kevésbé tekinthető hatékonynak (például a KNP esetében). Az alacsonyabb elfogadási érték (FHNPI) a szabadon látogatható területek alacsony arányára (KÁRPÁTI - FALLY 2012) is visszavezethető. A csak vezetôvel járható övezetek kijelölése nem csak a zónákat már kijelölt nemzetipark-igazgatóságok esetében értelmezhető, hatékonyságuk és elfogadottságuk között nincs jelentős eltérés. Kivételt képez a BfNPI, ahol az előírás betartatását - és ezért a hatékonyságát is - nagyon megnehezítik az igazgatóság humánerőforrás-adottságai mellett a terület földrajzi adottságai (utakkal és településekkel szabdalt térség) és turizmusának jellemzői (hazánk egyik leglátogatottabb turisztikai területe, nagyon változatos közönséggel).

Az útvonalról való letérés - melyet fokozottan védett területek esetén szintén jogszabály tilt - büntetése a jelentősebb természetjáró múlttal rendelkező területek esetében bizonyul kevésbé elfogadottnak (ANPI, BNPI, BfNPI, DINPI), illetve a természet védelme szempontjából hatékonynak. A csoportlétszám korlátozása ugyan egyformán elfogadott a szakemberek szerint az ANPI, valamint a BfNPI múködési területén, de az értékek védelme szempontjából a kisebb látogatóforgalmú ${ }^{4}$, fóleg regisztrációra alkalmas tevékenységet végző (illetve szolgáltatást igénybe vevő) turistákkal jellemezhető területen tekinthetô hatékonyabbnak (ANPI).

\section{5. Összegzés}

A védett természeti területeken alkalmazható látogatómenedzsment-eszközök és -intézkedések hazai helyzetének áttekintése alapján elmondható, hogy azok hatékonyságának és elfogadottságának megítélése változó az ökoturisztikai szakemberek körében. Ennek oka főleg az érintett terület adottságaitól (a kínált szolgáltatásoktól és így egyes

${ }^{4}$ Földművelésügyi Minisztérium: Nemzetipark-igazgatóságok látogatóstatisztikai adatai alapján (e-mail-ben történt adatszolgáltatás, 2016) 


\section{A látogatómenedzsment-intézkedések, -eszközök megítélése}

\section{a nemzetipark-igazgatóságok szakembereinek körében}

\begin{tabular}{|c|c|c|c|c|c|c|c|c|c|c|c|c|c|c|}
\hline \multirow{2}{*}{\multicolumn{2}{|c|}{\begin{tabular}{|c|} 
Válaszadók \\
Intézkedések, eszközök
\end{tabular}}} & \multirow{3}{*}{$\sum_{\bar{z}}$} & \multirow{3}{*}{$\begin{array}{l}\sum_{\infty} \\
3\end{array}$} & \multirow{3}{*}{ 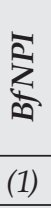 } & \multirow{3}{*}{ 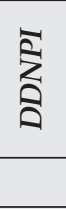 } & \multirow{3}{*}{ 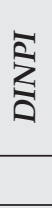 } & \multirow{3}{*}{ 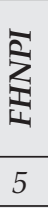 } & \multirow{3}{*}{$\underset{4}{\vdots}$} & \multirow{3}{*}{ 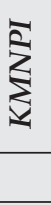 } & \multirow{3}{*}{$\sum_{2}$} & \multirow{3}{*}{$\begin{array}{l}\bar{\S} \\
:(4)\end{array}$} & \multirow{3}{*}{ 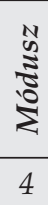 } & \multirow{3}{*}{ 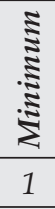 } & \multirow{3}{*}{ 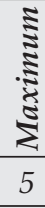 } \\
\hline & & & & & & & & & & & & & & \\
\hline \multirow{2}{*}{ Zónabeosztás kialakítása } & $H$ & & & & & & & & & & & & & \\
\hline & $E$ & & 4 & (1) & & & 2 & 3 & & 4 & (3) & 4 & 1 & 4 \\
\hline \multirow{2}{*}{ Motoros jármúvek kitiltása } & $H$ & & 3 & & 5 & 3 & 3 & 3 & & 4 & 4 & 3 & 3 & 5 \\
\hline & $E$ & & 3 & & 2 & 4 & 3 & 3 & & 2 & 3 & 3 & 2 & 4 \\
\hline \multirow{2}{*}{ Belépődij bevezetése } & $H$ & & 1 & & 3 & 5 & 3 & 4 & 4 & 2 & 4 & 4 & 1 & 5 \\
\hline & $E$ & & & & 3 & 5 & 4 & 5 & 4 & 3 & 4 & 4 & 3 & 5 \\
\hline \multirow{2}{*}{ Vezetett túra kialakítása } & $H$ & 3 & 5 & 4 & 5 & 3 & 4 & 5 & 5 & 5 & 5 & 5 & 3 & 5 \\
\hline & $E$ & 5 & 3 & 4 & 5 & 5 & 4 & 4 & 5 & 5 & 5 & 5 & 3 & 5 \\
\hline \multirow{2}{*}{ Csak vezetôvel járható övezetek } & $H$ & & 4 & 2 & 5 & 4 & 5 & 5 & 4 & 4 & 5 & 4 & 2 & 5 \\
\hline & $E$ & & 4 & 5 & 4 & 5 & 4 & 4 & 4 & 4 & 4 & 4 & 4 & 5 \\
\hline \multirow{2}{*}{ Turistautak időszakos lezárása } & $H$ & & 4 & & & & & 3 & (4) & & 2 & 4 & 2 & 4 \\
\hline & $E$ & & 3 & & & & & 3 & (4) & 4 & 2 & 3 & 2 & 4 \\
\hline \multirow{2}{*}{ Útvonalról való letérés büntetése } & $H$ & 3 & 1 & & 5 & 2 & & 3 & & 2 & 2 & 2 & 1 & 5 \\
\hline & $E$ & 3 & 3 & 2 & 4 & 2 & & 3 & & 2 & 2 & 2 & 2 & 4 \\
\hline \multirow{2}{*}{ Csoportlétszám korlátozása } & $H$ & 5 & 4 & 2 & 5 & 3 & 3 & 4 & (4) & & (4) & 4 & 2 & 5 \\
\hline & $E$ & 4 & 4 & 4 & 5 & 3 & 3 & 4 & (4) & & (3) & 4 & 3 & 5 \\
\hline \multirow{2}{*}{ Napi létszám korlátozása } & $H$ & & & & & & & & 5 & & (2) & & 2 & 5 \\
\hline & $E$ & & & & & & & & 5 & & (2) & & 2 & 5 \\
\hline Käzotéci tázolśáo meahatúrozáca & $H$ & & & & 5 & & & & & & (2) & & 2 & 5 \\
\hline Kovetest tavolsag megnatarozasa & $E$ & & & & 5 & & & & & & (4) & & 4 & 5 \\
\hline Turistaút nyomvonalának & $H$ & 5 & 3 & & (5) & & & & & & (1) & 5 & 1 & 5 \\
\hline megváltoztatása & $E$ & 4 & 3 & & & & & & & & (1) & & 1 & 4 \\
\hline & $H$ & & 3 & & (5) & & & & 4 & & (3) & 3 & 3 & 5 \\
\hline Alternativ utvonalak & $E$ & & 3 & & & & & & 4 & & (2) & & 2 & 4 \\
\hline Rendezvények létszámának & $H$ & 5 & 4 & 3 & 5 & 3 & & 4 & 4 & & 3 & 4 & 3 & 5 \\
\hline 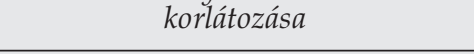 & $E$ & 4 & 4 & 4 & 5 & 3 & & 4 & 4 & & 1 & 4 & 1 & 5 \\
\hline Grométouúitöl kiholupóse & $H$ & 5 & & & (1) & 3 & & 3 & 4 & 3 & 1 & 3 & 1 & 5 \\
\hline szemetgyujtok kinelyezese & $E$ & 5 & & & (1) & 5 & & 4 & 4 & 5 & 4 & 5 & 1 & 5 \\
\hline & $H$ & 5 & & & 1 & 4 & 3 & & 5 & 2 & 4 & 5 & 1 & 5 \\
\hline szelektıv hulladekgyujtes & $E$ & 5 & & & 1 & 4 & 4 & & 5 & & 5 & 5 & 1 & 5 \\
\hline 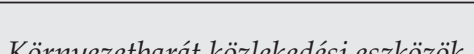 & $H$ & & 2 & & & & & 4 & & & 2 & 2 & 2 & 4 \\
\hline Kornyezetoarat коzleкеаеsi еszкоzок & $E$ & & 4 & & & & & 4 & & & 3 & 4 & 3 & 4 \\
\hline Srahad cátorzarxós tilalma & $H$ & 5 & 3 & 3 & 5 & 5 & 3 & 4 & & & 3 & 3 & 3 & 5 \\
\hline szabaa satorveres tilatma & $E$ & 4 & 3 & 3 & 3 & 3 & 3 & 4 & & 2 & 2 & 3 & 2 & 4 \\
\hline & $H$ & & & & & & & & & & (2) & & 2 & 2 \\
\hline Vizfogyasztas korlatozása & $E$ & & & & & & & & & & (2) & & 2 & 2 \\
\hline
\end{tabular}

Forrás: saját szerkesztés saját adatgyüjtés alapján

Megjegyzés: 1: nem ért vele egyet, 5: teljesen egyetért; zárójel: adott nemzetipark-igazgatóság működési területén nem vezették be, de a felmérés során a megkérdezett szakemberek értékelték az intézkedést; H: hatékonyság, E: elfogadottság. 
Lektorált tanulmányok

esetekben az eltérő vendégkörtől) függ. Emellett az egyes intézkedések hatékonysága (illetve bevezetésének lehetósége) a szakképzett munkaeró meglétén, illetve létszámán is múlik. A hazai nemzetipark-igazgatóságok azonban ez utóbbi tekintetében (főleg finanszírozási okok miatt) sajnos elég rosszul állnak.

A látogatómenedzsment-eszközként is felfogható intézkedések szélesebb körú alkalmazása, azok összes lehetséges előnyének tudatos kihasználása a célterületek értékeinek védelme mellett a látogatói élmény fokozásához, és így hosszú távon a természetvédelem elismertségének növekedéséhez és a bevételek emelkedéséhez is hozzájárulhat.

\section{Felhasznált irodalom}

BELL, S. - TYRVÄINEN, L. - SIEVÄNEN, T. PRÖBSTL, U. - SIMPSON, M. (2007): Outdoor Recreation and Nature Tourism: A European Perspective. Living Reviews in Landscape Research. 1(2). http://www.livingreviews.org/lrlr2007-2, Letöltve: 2017.12.05.

BENKHARD B. (2004): Relations Between IUCN-Zoning and Tourism In The Hungarian National Parks. Policies, methods and tools for visitor management. Proceedings of the second International Conference on Monitoring and Management of Visitor Flows in Recreational and Protected Areas. Rovaniemi, Finland. pp. 377-381.

EAGLES, P. F. J. - McCOOL, S. F. - HAYNES, C. D. (2002): Sustainable Tourism in Protected Areas Guidelines for Planning and Management. IUCN Publications. Thanet Press Limited, UK.

EAGLES, P. F. J. - McCOOL, S. F. (2004): Tourism in National Parks and Protected Areas. Planning and Management. CABI Publishing, UK.

KÁRPÁTI L. - FALLY, J. (szerk.) (2012): Fertô-Hanság - Neusiedler See-Seewinkel Nemzeti Park. Monografikus tanulmányok a Fertố és a Hanság vidékéról. Fertő-Hanság Nemzeti Park Igazgatóság, Budapest.

KVVM (KÖRNYEZETVÉDELMI ÉS VÍZÜGYI MINISZTÉRIUM) (2005): A természetvédelem ökoturisztikai koncepciója. KVVM, Természetvédelmi Hivatal, Budapest.

LEUNG, Y. - SPENCELEY, A. - HVENEGAARD, G. - BUCKLEY, R. (szerk.) (2014): Tourism and Visitor Management in Protected Areas. Guidelines for sustainability. IUCN Best Practice Protected Area Guidelines Series. https://iucn.oscar.ncsu. edu, Letöltve: 2017.12.08.

MICHALKÓ G. (2003): A fenntartható fejlődés ökoturisztikai aspektusai Magyarországon. Turizmus Bulletin. 2003/4. pp. 13-21.

NEWSOME, D. - MOORE, S. A. - DOWLING, R. K. (2001): Natural Area Tourism: Ecology Impacts and Management. Aspects of Tourism. Channel View Publications. Clevedon, Buffalo, Toronto, Sydney.

PÉNZES E. - CLARKE, A. - FORMÁDI K. JANCSIK A. - MADARÁSZ E. - MAYER P. PRISZINGER K. - RAFFAY Á. - BARÁZ CS. - KELEMEN Z. - KEVY A. - KOPEK A. - PANTALI B. - BERENCSI B. - GRUBICS M. - KÁROLY A. - LINGAUER J. (2008): Országos ökoturizmus fejlesztési stratégia. Pannon Egyetem, Aquaprofit Zrt., Veszprém - Budapest. http:// www.termeszetvedelem.hu/_user/downloads/ okoturizmus/okoturizmus_strategia_X.pdf, Letöltve: 2018. február 10.

PUCZKÓ L. - RÁTZ T. (2000): Az attrakciótól az élményig - A látogatómenedzsment módszerei. Geomédia Szakkönyvek, Budapest.

RÁTZ T. (2011): Attrakció- és látogatómenedzsment. In: Aubert A. (szerk): Turizmus-menedzsment. Elektronikus tananyag. http://www. eturizmus.pte.hu/szakmai-anyagok/Turizmusmenedzsment/book.html\#d6e2153, Letöltve: 2018. január 12. 